Виявлені зміни кровотоку у дітей з малими серцевими аномаліями свідчать про зниження кровотоку по хребтових артеріях 3 перерозподілом кровотоку у вигляді його збільшення по основній артерії. Дані зміни пов'язані з рефлекторною авторегуляцією судинного тонусу у відповідь на порушення вегетативного гомеостазу.

Аналізуючи венозний кровотік у дітей $з$ малими серцевими аномаліями, встановлено таку структуру порушень по v.jugularis: $з$ права $\epsilon$ домінуюче порушення венозного відтоку у вигляді якісних змін спектрограми над лівою (37,5 та 21,8\% відповідно).

Отже, враховуючи вищенаведені результати, мозковий кровотік, за даними УЗДГ дослідження, можна вважати задовільним у дітей 3 АПХ. Зміни 3 боку еластико-тонічних властивостей судин можна пов'язати з порушенням вегетативного балансу.

\title{
Література:
}

1. Гнусаев С.Ф., Белозеров Ю.М., Виноградов А.Ф. Клиническое значение малых аномалий сердца у детей. Медицинский вестник северного Кавказа. 2008; 2: 39-43.

2. Вейн А.М. ред. Вегетативные расстройства: Клиника, диагностика, лечение. М.: МИА, 2000. 752 с.

DOI https://doi.org/10.30525/978-9934-588-81-5-1.35

\section{DELAUNAY TRIANGULATION, VORONOI DIAGRAMS, CONVEX ANALYSIS AS BASIS FOR OPIMIZATION OF HEART ELECTRICAL INSTABILITY DIAGNOSIS}

\author{
Kulishov S. K. \\ Doctor of Medical Sciences, Candidate of Medical Sciences, \\ Professor at the Department of the Internal Medicine № 1 \\ Ukrainian Medical Stomatological Academy \\ Poltava, Ukraine
}

Introduction. Different technologies were used for analysis of heart electrical instabilities [1, 2, 3, 4, 5], but individual diagnosis by Delaunay triangulation, Voronoi Diagrams methods remain actual for cardiology $[1,2,3,4,5]$. The quality of heart arrhythmia and conduction disturbances diagnosis is derived by individual etiological and pathogenetic features $[1,2,3,4,5]$. Qualitative and quantitative characteristics of 2D, 3D electrocardiograms in the patients with pirouette ventricular pair extrasystoles gave us possibilities to determine peculiarities of oxymoron, 
fractal and antifractal, racemic Moebius strip like transitions and iteration $[6,7]$ (fig. 1).

The purpose of this study was to streamline of individual diagnosis by Delaunay triangulation, Voronoi Diagrams, convex methods for heart electrical instabilities diagnosis as prerequisite to treatment.

Methods. The object of study was 30 electrocardiograms with different types of heart electrical instabilities. We used algorithm for diagnosing heart electrical instability, which reduces to qualitative and quantitative analysis of electrocardiograms (ECG) in standard, inverted, 3D (as rotation bodies of ECG elements) forms; constructing graphs, including "Gift wrapping" algorithm; Delaunay triangulation, Voronoi Diagrams analysis, calculation distances between points, angles between arcs, graphs; comparison of qualitative and quantitative characteristics of these arcs, graphs; the rotation volume, surfaces of the electrocardiograms elements; formulation of the diagnostic conclusion.
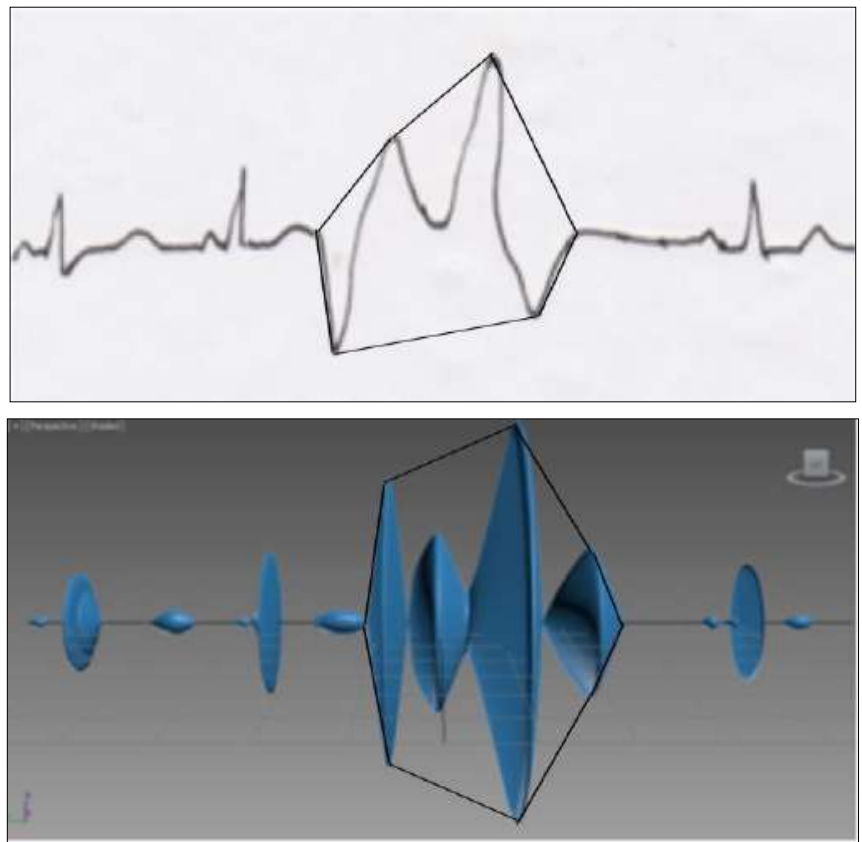

Fig. 1. The convex hull of complexes and rotation bodies of electrocardiogram elements as Moebius strip like constituents in the patients with pair pirouette ventricular premature beats [6] 
We were used Typical Conceptual Spaces by some general principles [8] and our concepts of it $[4,5]$.

Results. We determinate disturbances of heart rhythm and conductivity components as unity of opposites, antonyms; oxymorons [1, 2, 3, 4, 5]. Qualitative and quantitative characteristics of electrocardiograms in the patients with heart electrical instabilities, including pirouette ventricular pair extrasystoles, pirouette ventricular tachycardia gave us possibilities to determine peculiarities of oxymoron, fractal and anti-fractal, racemic Moebius strip like transitions and iteration [6,7].
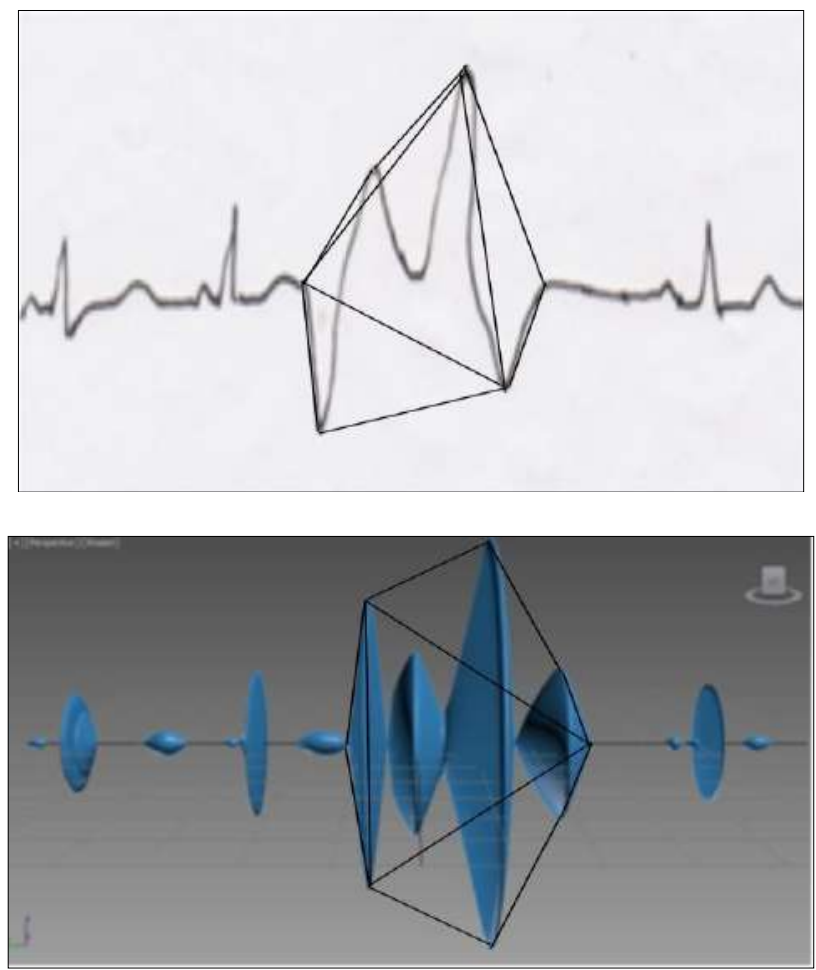

Fig. 2. Delaunay triangulation ECG analysis in the patients with pair pirouette ventricular premature beats

The rotation volume of the spin dependent electrocardiograms elements showed the performed depolarization and repolarization work in the atria and 126 
ventricles as a derivative of speed and time $[4,5]$. The surface of such bodies reflects the front of movement of electromagnetic waves. Qualitative and quantitative characteristics of 3D electrocardiograms gave us possibilities to determine peculiarities of rhythm and conduction disturbances $[4,5]$.
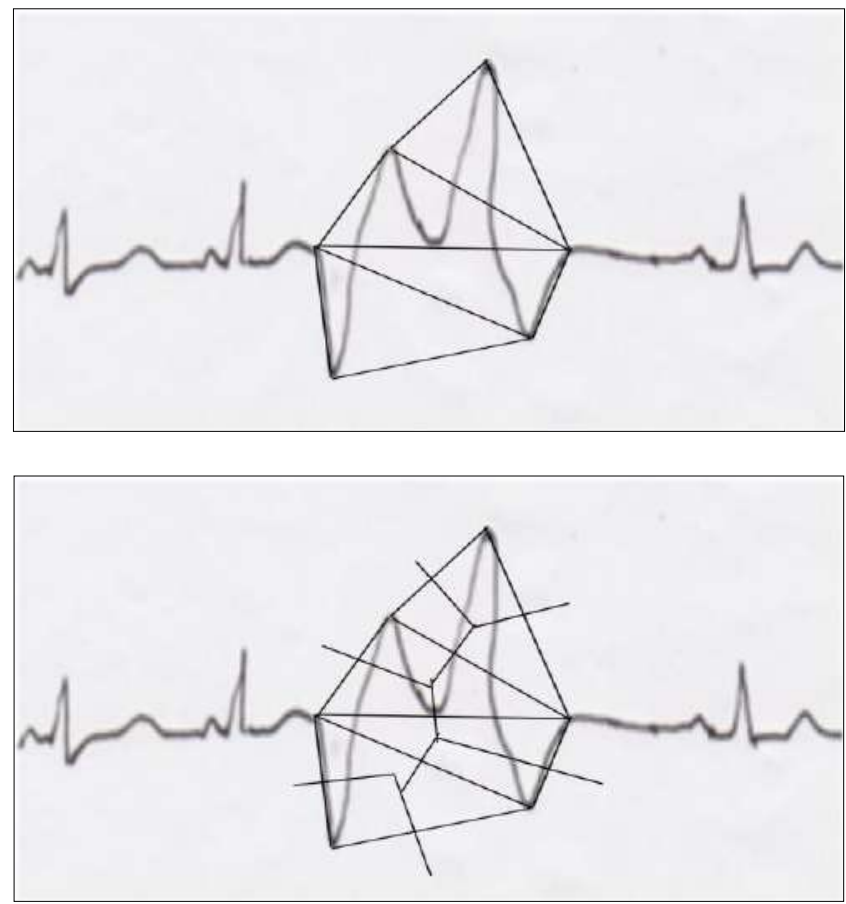

Fig. 3. Delaunay triangulation and Voronoi Diagrams ECG analysis in the patients with pair pirouette ventricular premature beats

Discussion. The proposed technology of heart electrical instability analysis by using Delaunay triangulation and Voronoi Diagrams, convex ECG analysis promotes understanding of heart electrical instability mechanisms, improves the quality of diagnosis as precondition to correct of the treatment. Electrical instability of the heart is derived from its structural and electrical remodeling $[1,2,3,4,5,6]$. Characteristics of volume, surface, spin, chirality of rotation bodies of electrocardiogram elements give us possibilities to determine depolarization and repolarization electro-magnetic picture, oxymo- 
ron, fractal and anti-fractal, Moebius strip like transitions and iteration, state of electrical heart instabilities [2, 3, 4, 5, 6, 7].

Conclusion. Delaunay triangulation, Voronoi Diagrams, convex analysis of electrocardiograms gave us possibilities to improve the quality of heart electric instability mechanisms diagnosis.

Such mathematical methods are a prerequisite for a better understanding of treatment directions.
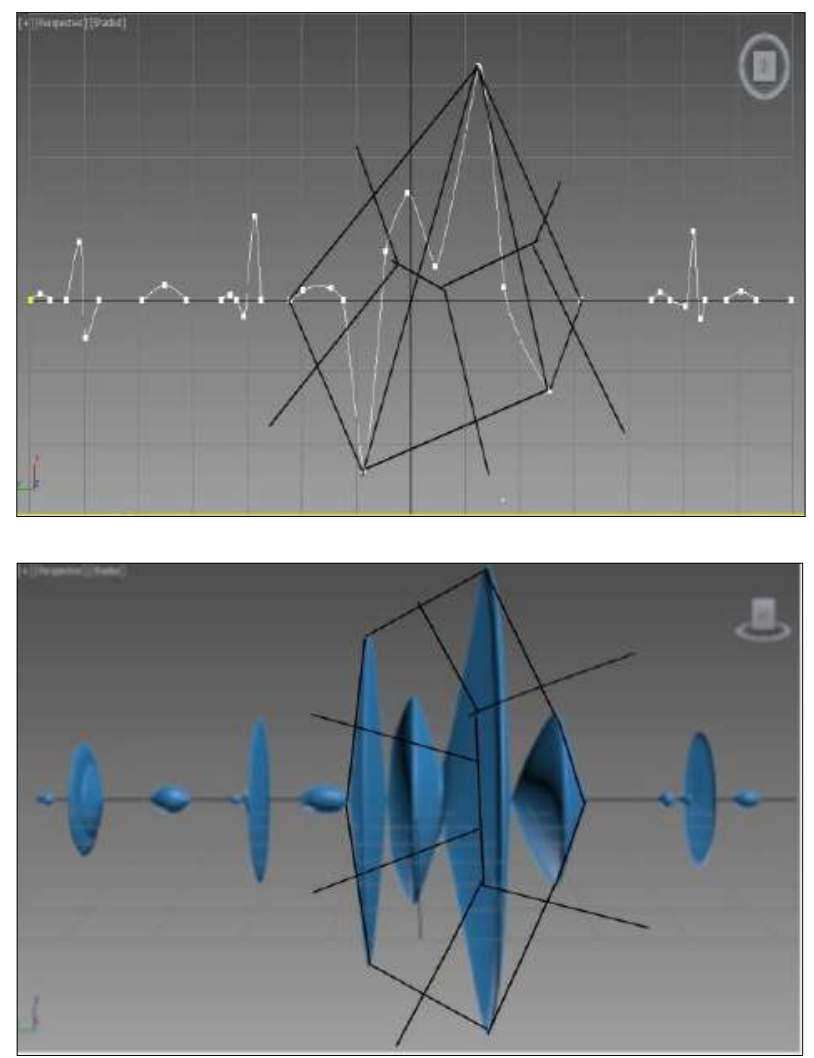

Fig. 4. The convex hull of complexes and rotation bodies of electrocardiogram and Voronoi Diagrams analysis in the patients with pair pirouette ventricular premature beats 


\section{References:}

1. Kulishov S.K., Iakovenko O.M. Myocardial electrical instability, arterial hypertension as objects for convex and fractal, anti-fractal analysis, optimization of diagnosis. Book of program and abstract of International Conference on Nonlinear Analysis and Convex Analysis (NACA, 2015, Chiang Rai, Thailand, January 21-25, 2015), 2015. P. 84.

2. Kulishov S.K. Oxymoron like pathology: mechanisms, diagnosis, treatment correction: Publisher : CreateSpace Independent Publishing Platform; 1st Edition. 2018. 104 pages.

3. Kulishov S.K. Modeling of cardiac arrhythmias and blockades as the unity of fractal and anti-fractal antonyms. International journal of mathematical models and methods in applied sciences. 2019. Vol. 13. P. 35-39.

4. Kulishov S. Mathematical Modeling of Heart Electrical Instabilities by using Topology, Convex Analysis, Conceptual Spaces, Graph Theory. Proceedings of Mathematics and Computers in Science and Engineering, MACISE, 2019; 19-21 January 2019; Madrid, Spain; IEEE Computer Society; Conference Publishing Services; 2019, December 30; The Institute of Electrical and Electronics Engineers, Inc., BMS Part Number: CFP19S31-ART; 2019. P. 5-9; DOI:10.1109/MACISE.2019.00008

5. Kulishov S.K. Heart Electrical Instabilities: Some Mechanisms by Topology, Symmetry, Spin, Semiotics; Diagnosis. Global Journal of Medical Research: K Interdisciplinary; Publisher: Global Journals Online ISSN: 2249-4618 \&Print ISSN: 0975-5888. 2020. Vol. 20. Issue 6. Version 1.0. P. 23-29.

6. Kulishov S, Racemic Moebius Strip Like Heart Arrhythmias: Mechanisms, Mathematical Modeling, Diagnosis Heart Rhythm. Congress (HRC); 6-9 October 2019; International Convention Centre (The ICC); Birmingham UK. European Journal of Arrhythmia \& Electrophysiology 2019, 5 (Suppl. 1): abstr169. P. 94-95.

7. Kulishov S. Racemic Moebius Strip Like Heart Arrhythmias: Mechanisms, Mathematical Modeling, Diagnosis Heart Rhythm. Congress (HRC); 6-9 October 2019; International Convention Centre (The ICC); Birmingham UK; e-poster: ResearchGate - DOI: 10.13140/ RG.2.2.33503.41124.

8. Gärdenfors P., Williams M-A. Reasoning about categories in conceptual spaces. In Proceedings of IJCAI 2001. Morgan Kaufmann Publishers. 2001. P. 385-392. 